of the lava currents of Auvergne. M. Lecoq had in his museum some fossil remains of the Marmot, the Mammoth, and the tichorhine Rhinoceros, and he distinctly told us that these relics of northern mammalia, which geologists are accustomed to associate with glacial times, were mostly found in craclis and fissures in the lava-streams near Clermont Ferrand. From this it would appear that the latest lava streams of Auvergne had become cold, consolidated, and fissured before the introduction of the bones and teeth of the northern quanrupeds into the fissures.

But if this prove to be true, on further investigation, I do not wish to imply that there have been no volcanic eruptions in Central France since the last outpour of lava currents, or the days of the Mammoth. On the contrary, I think the $\epsilon$ vidence is the other way. I have just returned from a visit to the extinct volcanos of the Haute Loire and the Ardêche, where I was accompanied by my friends Sir William Guise, Capt. Price, and Mr. Lucy; and I believe there is evidence of a certain amount of volcanic action in the Ardêche since the outpouring of the later lava-streams. There are outbursts of volcanic ash and scoriæ which form what are termed "chimneys," and which are blown right through the most recent lava-currents. Both near Montpezat, so admirably depicted by Mr. Scrope, and near the bridge at La Beaume, there are outbursts and eruptions through the basalts, which dislocate and throw off the basaltic columns. It is not improbable that some of these attempts at forming a volcano happened in the Ardêche during the fifth century, when the Archbishop of Vienne, Alcimus Avitus, in his homily on the "Rogation Days," speaks of "frequent shocks of earthquakes,", and "fires often blazing," and "piled up mounds of ashes." Gregory of Tours also speaks of stags and wolves wandering about Vienne. These wild animals may have been driven from the forests of the Arôêche, by these last volcanic eruptions, as far as Vienne.

W. S. SYMONDS

\section{Communication of Information among Bees}

SOME two or three years ago a swarm of bees entered a very small hole under the slates near the eaves of the roof of my house in the Highlands, and established themselves for the summer but died out in the subsequent winter. I infer that there were no survivors among the bees to remember the circumstance (see Appendix to Kirby and Spence's "Entomology") and to account in any degree for what occurred this summer.

The house is of four stories, and stands in the garden, in which, akout fi:ty yards from the house, on the other side of a hadge, are my beehives. For a few days, during which there were the usual indications of swarming being imminent in one of the hives, a great many bces found their way into the lower rooms of the house; there was a constant hum of bees in one of the chimneys, at the top of which there was always a group flying about. The top of this chimney is about thirty feet horizontally from the settlement of the old swarm, and fifteen feet above it; there was also occasionally a cluster of bees on the roof of a "semi-detached" lower building (the kitchen) on the other side of the house from the old settlement, but as far as we saw no bees visited the old settlement, and nothing indicated any intention of the swarm to go there, though we expected it to make for the house and probably for the chimney I have mentioned. In due time the swarm came off and rose unusually high, and I immediately made some smoke in the chimney to prevent their entering it. Prcsently the swarm settled on a low apple-tree and was snugly hived in the usual way in a straw "skep" about noon. Next day, however, about Io A.M., the swarm left its "skep" and made for the old settlement without any hesitation, and there they established themselves in spite of all we could do.

Of course the whole proceedings may have been disconnected, but the impression left on my mind was that the queen, or her counsellors, had previously "prospected," and resolved to go to the old settlement as an eligible "location," and that the common bees learned somehow that "the house" was to be their destination, but that some of them fancied the chimney, others the roof of the kitchen, and others wandered vaguely in at various open window's, while the queen knew exactly where she wanted to go, but got confused the first day.

The manner in which the bees learned that the house was to be their destination may have been that the queen in her investigations had left strong traces of herelf at the chimney and on the roof of the kitchen, which attracted the bees to these places, and a general odour of royalty about the house which induced the bees to come in at the windows; but it may have been that there was some "talk" in the hive about it. In connection with
Sir John Lubbock's papers, the incidents may be worth your notice.

There has also been some question as to the distance bees go in search of "pasture." It may be worth noting that at Arisaig House, $I$ am told, bees are to be found in the peach-house every spring at the time of the blossom, while, so far as I can learn, there are no hives within ten miles but my own, which are separated from it by an arm of the sea (Loch Ailort), a mile wide with islands, and a second arm of the sea (Loch-na-Nuadh), two miles wide without islands, the whole distance being about four miles from the hives to the peach-house.

University of Glasgow, Nov. 13 Hugh BLACKBURN

\section{A New Palmistry}

I HAVE lately consulted two standard works upon the pro. portions of the human figure to which Prof. Ecker does not refer in the suggestive paper of which I gave an abstract in NATURE (vol. xiii. p. 8), in the hope of finding some definite information as to the relative lengths of the "index" and "ring" fingers. In the first of these two works, Quetelet's "Anthropométrie" (Bruxelles, I 870), no mention whatever is made of the proportions of the several digits, whether of hand or of toot; while from the second authority, the "Proportionslehre" of Carl Gustav Carus (Leipzig, 1854), all the infor. mation that can be derived, meagre as it is, is purely inferential. In the skeleton of a hand represented at Fig. 4, Taf. iii. of this fine folio work, the "index" is considerably longer than the "ring" finger; and in the letter-press explanatory of this plate, a table is given of the lengths of the various factors of the digits, e.g. the metacarpals and the three phalanges, in " modulminutes," constant lengths, each of which is equivalent to about seven millimetres. Now the length of the "index" is twenty. three, while that of tire "ring" finger is only twenty " modulminutes," the former thus exceeding the latter digit by about twenty-one millimetres, a difference much greater than any which has been recorded by Prof. Ecker. In the extended left hand of an ideal (sexless) figure, at Taf. iv. (ibid.), the "ring" and "index" digits are of the same length, the former being perhaps a shade longer.

Regiments and large asylums would be a fertile field for the further investigation of this interesting and highly suggestive subject.

J. C. GalToN

IN Mr. J. C. Galton's interesting article bearing the above title, in NATURE, vol. xiii. p. 8 , no mention is made of the position of the hand at the time of making the observation as to the comparative length of the fingers. Perhaps Mr. Galton will kindly make it known whether Dr. Ecker has specified the position which he adopted. That the position niakes some dif. ference may be clearly seen in the following manner:--

Place the hand, back upwards, horizontally across the front of the chest, and observe the comparative length of the "index" and " ring" fingers. Then, by a motion of the wrist, moving the arm as little as possible, turn the hand outwards in the same plane, until the fingers stand at right angles to their first position, and again observe the two fingers. Naturally the "index" will appear to be longer in the first position than in the second, on account of the different condition of the muscles. Neither of these positions is likely to be adopted by anyone investigating the subject, but in any comparison of results one and the same position should be referred to as a standard, and this standard should specify whether the hand is held with the back or the face upwards. Dissimilarity between the two hands, as mentioned by $\mathrm{Mr}$. Pryor, appears to be common. F. T. MOTT

Leicester, Nov. 19

I HAVE made a collection of over fifty outlines of the fingers of European hands (right and left). At present I find that the tendency in the female hand is to a proportionately longer third than index, in both hands, than in the male. In all the hands I have examined, the third finger of the left hand (when longex than the index) is also proportionately longer than the same finger of the right. In this series I have found only one case of an index longer than the third, and only one in which they were equal (both males). These are all carefully drawn into a pocketbook, care being taken that the hand is perfectly free from any muscular strain, which alters the result very appreciably; and the race, sex, and general physical characteristics are noted on the sheet. The list at present includes some eminent classical 